\title{
Incorporating Local Wisdom into the Consumer Protection Legal Regime: A Comparison between Indonesia and Australia
}

\author{
I Gusti Ngurah Parikesit Widiatedja*
}

Ph.D Student at Melbourne University School of Law

\begin{abstract}
Globalization has affected legal services and converged legal systems, especially in consumer protection in Indonesia and Australia. This process has resulted to a more formal, transparent, and adversarial laws and regulations that typically reflect to the common Law system. Then, the incorporation of local wisdom encourages significantly for the receptiveness of this globalization and convergence process both in Indonesia and Australia. This paper will show and analyze the extent to which globalization has affectedconsumer protection in Indonesia and Australia by dividing the impact from the result of economic liberalization and political fragmentation. It will then show how the incorporation of local wisdom canaccelerate the globalization of legal services and convergence of legal systems on consumer protection in Indonesia and Australia
\end{abstract}

Keywords: Local Wisdom, Consumer Protection, Law, Indonesia, Australia.

\section{INTRODUCTION}

According to Duncan Kennedy there are three conceptual periods of institutional and legal theory development: classical legal thought, the social, and the current globalization that he described as an unsynthesized coexistence of transformed elements from both first and second thought. ${ }^{1}$ According to Keleman, the globalization has spread common law style legal thinking around the world that has been propelled by economic liberalization and political fragmentation. ${ }^{2}$ These two factors have resulted in the transformation of modes of governance from informal, opaque, and cooperative to be formal, transparent, and adversarial ones. ${ }^{3}$ According to Kagan, this outcome typically reflected the adversarial legalism that consists of three essential elements, namely policy making, policy implementation, and dispute resolution ${ }^{4}$.

Consumer protection is one of the most developed areas of law and has progressively adopted the rule of professional law, ${ }^{5}$ and the spirit of adversarial

* Corresponding: iwdiatedja@student.unimelb.edu.au

${ }^{1}$ Duncan Kennedy, Three Globalizations of Law \& Legal Thought: 1850-2000, in Trubeck, David and Santos, Alvaro, eds., The New Law \& Economic Development Movement: A Critical Appraisal (New York: Cambridge University Press, 2006), 127.

${ }^{2}$ Daniel R Kelemen and Eric C. Sibbitt, “The Globalization of American Law," Journal of International Organization, vol. 58 (2004): 103.

3 Ibid. 105.

${ }^{4}$ Robert A. Kagan, Adversarial Legalism The American Way of Law (Boston: Harvard University Press, 2003), 9.

5 Ugo Mattei, "Three Patterns of Law: Taxonomy and the Change in the World's Legal Systems," American Journal of Comparative Law 45, No. 5 (1997): 12-13. 
legalism as an inescapable impact from globalization and convergence of law. Adversarial legalism is a main distinctive feature of the United States' (US) and the United Kingdom (UK) legal systems. Formal legal contestation and litigant activism are the most crucial characteristics of this system, distinguishing them from other legal systems around the world. ${ }^{6}$ One of the most inseparable parts from adversarial legalism is adversarial civil procedure. Under this mechanism, two parties, both plaintiff and defendant, play a dominant role. As justice seekers, they contend ardently in finding miscellaneous legal facts, rights, and duties by presenting evidence and arguments. In this scenario, a judge posits himself as a passive and neutral party acting as a referee who assures that the trial process complies with procedural requirements.

As an active nation in international relations, Indonesia has been affected substantially by the globalization of legal services and convergence of legal systems, especially in consumer protection. In Australia, this process involved the Australian and New Zealand economies that are becoming increasingly integrated. This has arisen in the context of shared legal and political heritages, geographical proximity and similarity of policy measures adopted by Governments in both countries. ${ }^{7}$ One important similarity on the convergence of legal systems is the incorporation of what has been regarded as local wisdom.

This paper will analyze and compare the impact of globalization on consumer protection in Indonesia and Australia by dividing the impact from the result of economic liberalization and political fragmentation. Then, each elucidation will encompass the level of policy making and policy implementation. Lastly, this paper will also analyze and compare how the incorporation of local wisdom can avail the receptiveness of the globalization of legal services and convergence of legal systems on consumer protection in Indonesia and Australia.

\section{ANALYSIS}

\subsection{Economic Liberalization}

It is unmistakable that the increase of globalization has been encouraged by economic liberalization. This ensued when many nations committed to the bilateral and multilateral free trade agreements, gradually reduced financial regulations, opened their markets to foreign investment or service providers and eliminated other cumbersome procedures in business transactions. ${ }^{8}$ The

6 Ibid.

7 Arlen Duke, "Representations as to the Future Under the Proposed Australian Consumer Law" Melbourne University Law Review 33, No. 2 (2009): 41.

8 See further explanation at I Gusti Ngurah Parikesit Widiatedja, Liberalisasi Jasa dan Masa Depan Pariwisata Kita (Liberalization of Services and our Tourism Future), (Denpasar: Udayana University Press, 2010), 36-37. 
arguments for economic liberalization also include larger efficiency and effectiveness thatdiminish poverty and unemployment and increase the living standards of people, especially in the least developed countries. ${ }^{9}$

Economic liberalization was formally embodied through comprehensive negotiations of trade in the Uruguay Round. At that unprecedented moment, 123 nations agreed to establish the World Trade Organization (WTO) as the successor of the General Agreement on Tariffs and Trade (GATT). ${ }^{10}$ It would be a stepping stone to extend the economic liberalization because of its substantial coverage encompassing investment, intellectual property rights and services as a part of tradable activities.

Indonesia bound itself through promulgating Law No. 7 of 1994 regarding the Ratification of Agreement of Establishing the WTO. The increasing performance of economic development was an essential consideration in ratifying its agreement that progressively allowed the operation of foreign providers. ${ }^{11}$ As an affirmative action, government has enacted many laws that have adopted progressive economic liberalization. ${ }^{12}$

In consumer protection, the government of Indonesia promulgated Law No. 8 of 1999 that comprehensively regulated the protection for consumers in Indonesia. The objective of this law can be categorized from the government, consumers, and entrepreneurs' perspective. From the government perspective, this law intended to devise a consumer protection system containing legal safety and transparent information. ${ }^{13}$ Concerning the consumer perspective, this law expected to improve the ability of consumers to select, determine and claim their rights as consumers. ${ }^{14}$ From the entrepreneurs perspective, this law aimed to strengthen the quality of the goods and services by forming an honest and responsible behavior in conducting business. ${ }^{15}$

In terms of policy making and policy implementation, the law of consumer protection represents a transparent principle that is typical to common law systems

9 See further in the preamble of Agreement of Establishing the WTO and the preamble of the GATS

10 Peter van den Bossche, The Law and Policy of The World Trade Organization, (New York: Cambridge University Press, 2010), 18.

${ }^{11}$ It was expressly stated on consideration of Law No. 7 of 1994 concerning the Ratification of Agreement on Establishing the World Trade Organization.

12 For example, Law No. 10 of 1998 concerning Banking Systems, Law No. 8 Of 1999 concerning Consumer Protection, Law No. 36 of 1999 concerning Telecommunication, Law No. 30 of 1999 concerning Arbitration Council, Law No. 30 of 2000 concerning Trade Secret, Law No. 32 of 2000 concerning Electronic Circuit Design, Law No. 14 of 2001 concerning Patent, Law No.15 of 2001 concerning Trademark, Law No. 19 of 2002 concerning Copyright, Law No. 25 of 2007 concerning Investment, Law No. 40 of 2007 concerning Limited Liability Company, Law No. 11 of 2008 concerning Electronic Transaction, and Law No.10 of 2009 concerning Tourism.

${ }^{13}$ Law No. 8 of 1999 , Art. 3.

14 Ibid.

15 Ibid. 
and legal practice. ${ }^{16}$ It is because this lawprovides detailed and elaborated rules and regulatory procedures as well as extensive disclosure requirements. ${ }^{17}$ Specifically, this law required all entrepreneurs both foreign and domestic to produce and guarantee the goods and services based on the prevailing quality standard provisions. ${ }^{18}$ Then, there are several administrative requirements for entrepreneurs including all products must be made to the Indonesian National Standard which is the only applicable standard in Indonesia; ${ }^{19}$ they must have a manual book and after sale warranty card in Indonesian language; ${ }^{20}$ they must pass technical rules and procedures for supervision of goods and services; ${ }^{21}$ and they must have labels on goods. ${ }^{22}$

Equally important, this law also indicates the role of the government to protect self-realization of individual rights that were derived from classical legal thought ${ }^{23}$ and the concept of rule of professional law. ${ }^{24}$ There are several rights for consumers. Firstly, the right to safety, that means the right to be protected against the marketing of goods and services, which are hazardous to life and property. ${ }^{25}$ Secondly, the right to choose, that means the right to be assured, wherever possible, of access to a variety of goods and services with competitive prices. ${ }^{26}$ Thirdly, the right to be informed about the quality, quantity, potency, standard, and price of goods and services. ${ }^{27}$ Finally, the right to redress, that means consumers must obtain compensation, redress or substitution if the products received are not in accordance with the agreement or not received as requested. ${ }^{28}$

Furthermore, this law has elaborately defined prohibited actions for the entrepreneurs while producing and trading goods and services. They have to follow these requirements including the following: meet or accord with the required standard and provisions of the law; accord with the net weight net volume, and the total amount as stated on the label of the said goods; accord with the actual size, measurement and total amount; accord with the condition, guarantee, specialty or efficacy as

\footnotetext{
${ }^{16}$ Keleman and Sibbit, Op.Cit., 106.

17 Ibid. 109.

18 Law No. 8 of 1999, Art. 6.

19 Governmental Regulation No. 102 of 2000 concerning National Standardization.

${ }^{20}$ Minister of Trade Decree No. 19/m-dag/per/5/2009 concerning Registration Manual and Card Guarantee/Warranty for Sale in Bahasa for Telematica and Electronic Products.

${ }^{21}$ Minister of Trade Decree No. 20/m-dag/per/5/2009 concerning Rules and Procedures For Goods and/or Services Control.

${ }^{22}$ Minister of Trade Decree No. 22/m-dag/per/5/2010 concerning Amendment of Minister of Trade Decree No. 62/m-dag/per/12/2009 concerning Responsibility of Label Inclusion in Goods.

23 Kennedy, Op.Cit., 26

${ }^{24}$ Mattei, Three Patterns of Law, 14.

${ }^{25}$ Law No. 8 of 1999, Art. 4(a).

26 Ibid. Art.4(b).

27 Ibid. Art.4(c).

28 Ibid. Art.4(h).
} 
stated on the label or information of the said goods and/or services; accord with the promise as stated on the label information, advertisement or sales promotion of the goods and/or services; mention expiry dates or best before for the use of the goods and/or services; include information and/or directions on the use of the goods in Indonesian language to conform with the prevailing provisions of the law. In addition, entrepreneurs are prohibited from trading damaged, defective or used and tainted goods without providing complete and correct information. ${ }^{29}$

These efforts in defining consumer rights and prohibited actions are effective to educate and empower consumers to be less reluctant litigants ${ }^{30}$ for asserting their rights. Furthermore, they also believe they will gain incentive from using this law. ${ }^{31}$ In this context, they can receive better quality and transparent information of goods and services after asserting their rights as consumers. For instance, from May to December 2013, National Consumer Protection Agency has received 1,700 complaints from consumers because they felt dissatisfied related products purchased. The complaints related to banking, consumer finance, housing, transportation, insurance, electricity, telecommunications, water, and service delivery. ${ }^{32}$

Besides, the Financial Services Authority (OJK) received up to 1,078 complaints from January to June 2014 due to the lack of financial services. The public's complaints usually mentioned violations by financial authorities over financial services, disputes between customers and financial services and complaints of which the OJK had no authority to settle. In general, from 2013 to June 2014, the OJK received 15,000 service requests, which comprised 1,967 complaints, 1,230 information inquiries and the rest being questions. Around 47 percent of complaints concern problems with banks, 43 percent involve non-bank issues and 3.1 percent concern the stock market. ${ }^{33}$

With respect to dispute resolution, the consumer protection law and regulations express the empowerment of private actors to assert legal rights. It is because they provide extensive causes of action or remedies as a part of product liability procedures that typically associate with the American legal style. ${ }^{34}$ After receiving complaints from consumers, the government will identify meticulously defective products, and then punish manufacturers and sellers. For example, when a dentist

29 Ibid, Arts. 8 (1) and (2).

30 This is inspired by John Owen Haley, "The Myth of the Reluctant Litigant," Journal of Japanese Studies 4 (2), No. 359 (Summer 1978).

31 Daniel Berkowitz, Katharina Pistor, and Jean-Francois Richard, "The Transplant Effect," American Journal of Comparative Law 51 (2003): 163.

32 Wji Nurhayat, Dalam 6 Bulan ada 1700 konsumen mengadu ke BPKN (in six months, there are 1700 consumers who complaint to BPKN), Des.12.2013, http://finance.detik.com/read/2013/12/11/133 841/2438818/4/dalam-6-bulan-ada-1700-konsumen-ngadu-ke-bpkn?9911012

331078 complaints to OJK in first half of 2014, The Jakarta Post, June 16,2014, http:/ / www.thejakartapost.com/news/2014/06/16/1078-complaints-ojk-first-half-2014.html

34 Keleman and Sibbit, Op.Cit., 107. 
bought a Dental Unit produced by a European company, there were some specifications that did not match as agreed. Next, the Ministry of Trade took an investigation by requesting information from both the representative and consumer. However, due to insufficient data, the Ministry of Trade directly sent inquiries to the manufacturer. Next, the manufacturer appointed its representative for Southeast Asia to solve this complaint. Finally, the manufacturer agreed to provide compensation (refund) for consumer. ${ }^{35}$ Besides, National Agency of Food and Drug control recalled milk products from China because of tainted melamine in $2010 .{ }^{36}$

Meanwhile, The National Police have called on the public to join the global fight against counterfeit goods to deter the growing circulation of counterfeit goods in Indonesia. In 2013, the National Police investigated 589 cases of intellectual property rights violations. Specifically, some counterfeited electronic and automotive brands are Canon, Hewlett-Packard, Microsoft, Honda and Toyota. Fashion labels commonly ripped off include Louis Vuitton, Chanel and Gucci. ${ }^{37}$

Equally important, consumer protection law also provides a class action mechanism for private actors to assert their rights. It states that the main prerequisite for a class action lawsuit is a group of consumers with the same interest. ${ }^{38}$ Accordingly, the Supreme Court of Indonesia enacted the procedure on filing a class action lawsuit in 2002. ${ }^{39}$ This regulation is a comprehensive guidance for courts all around Indonesia in cases of class action. For example, one dispute that went to court was a case involving a price increase of liquefied petroleum gas (LPG) between consumers represented by several non-governmental organization and producer of LPG, Pertamina, a state owned enterprise. ${ }^{40}$ The basis for the lawsuit was the Pertamina's arbitrary decision to increase $40 \%$ of the price of LPG without any prior notice. ${ }^{41}$ The court in its decision ruled that the Pertamina has committed a tortious conduct by increasing the price of LPG arbitrarily without any prior notice. Furthermore, the court declared the decision to increase the price was invalid, and then instructed Pertamina to annul the decision. ${ }^{42}$

35 Eric Nababan, Major Consumer Protection Law Enforcement and Consumer Issues in Indonesia. August 27, 2012, http://aseanconsumer.org/misc/downloads/usftc-s2-Indonesia-Eric-Nababan.pdf

36 National Agency of Food and Drug Control, "Indonesia Food Recall System," May 6, 2010, http:// fscf-ptin.apec.org/docs/events/food-safety-recall-system-development-and-strengthening/Appendix\%20 19.pdf

37 Yuliasri Perdani, Police Call Concerted Effort Stop Counterfeiting, The Jakarta Post, June 6, 2014, http:/ /www.thejakartapost.com/news/2014/06/06/police-call-concerted-effort-stop-counterfeiting.html

38 Law No. 8 of 1999, Art. 46.

39 The Supreme Court Regulation (PERMA) No. 1 of 2002 concerning Class Action.

40 Civil Case No. 550/PDT.G/2000/PN.JKT.PST.

41 Ibid.

42 Ibid. 


\subsection{Political Fragmentation}

Historically, Indonesia has a notorious record of governance and bureaucratic legalism ${ }^{43}$ that tended to produce repressive laws and regulations. ${ }^{44}$ At that period, the centralized legal system boosted an oligarchic economy in which political and business elites collaborated ${ }^{45}$ to exploit economic resources in Indonesia in order to establish and preserve political stability and strong economic growth. Moreover, judicial control was very weak and held the status of a non-independent legal institution because the department of justice was an executive power. ${ }^{46}$

Regarding consumer protection, the legal basis for consumer tort was regulated vaguely under Article 1365 of Indonesian Civil Code. Furthermore, most Indonesian consumers had a poor awareness of their rights, and rarely disputed defective products. If they bought defective products, they usually just accepted them. Some may return the defective goods to the store, but they were very reluctant to bring the dispute to the formal agency. Moreover, consumers had a very limited option to consume products since products were mostly produced by entrepreneurs who had a close relationship with political power.

As a part of the reformation process, the laws and regulations concerning consumer protection have adopted progressively a political fragmentation since 1999 . In terms of policy making and policy implementation, the consumer protection law has established several agencies that have fragmented authority. Hence, these figures reflect adversarial legalism that has resulted in more complex agencies that were supported by detailed guidelines and procedures in governing consumer protection in Indonesia. Specifically, the National Protection Consumer Agency has a main objective to receive complaints from the consumer and to suggest technical and administrative policies to the government. ${ }^{47}$ Besides, the non-governmental Consumer Protection Foundation has responsibilities to advocate consumers' rights, and to represent consumers in their cases. ${ }^{48}$

Furthermore, Consumer Dispute Settlement Agency has a main objective to resolve a dispute outside the court. ${ }^{49}$ For administrative guidelines and procedures, Ministry of Trade verified the requirement of Indonesia Mandatory Standard, ${ }^{50}$ and

43 Kagan, Adversarial Legalism The American Way of Law, 10.

44 Refers to opponent of responsive law from Philipe Nonet and Philip Selznik, Law and Society in Transition: Toward Responsive Law, (New York: Harper and Row, 1978), 36.

45 Keleman and Sibbit, Op.Cit., 132.

46 Erman Rajagukguk, "The Prospect of Legal Institutions Reform in Indonesia," http: / /www.ermanhukum.com/Makalah\%20ER\%20pdf/The\%20Prospect\%20of\%20Legal\%20Institutions $\% 20$ Reform\%20 in\%20Indonesia.pdf

47 Law No. 8 of 1999, Art. 34.

48 Ibid, Art 44.

49 Ibid. Art 49.

50 Governmental Regulation No. 102 of 2000 concerning National Standardization. 
National Agency of Drugs and Food Control verified food products, cosmetics, medicine, and medical devices. ${ }^{51}$ In 2010, Ministry of Trade established a Directorate General for Standardization and Consumer Protection in a bid to enhance its efforts to protect consumers from faulty and non-standardized products. ${ }^{52}$

As a reflection of fragmented authority and how the legal elites try to participate in devising national strategies to direct economic and social change ${ }^{53}$ in consumer protection, some departments have shown their active role to assure the protection and safety of consumers by making responsive regulations. For example, the Ministry of Transportation issued a regulation on air carrier liability. This regulation, which adopted the Montreal Convention of 1999, stated that every commercial air transport in case of delay shall provide compensation for the amount of 300.000,00 rupiah (30 US\$) if they delay the flight more than 4 hours. ${ }^{54}$ For consumers in the tourism sector, the Ministry of Tourism issued a regulation regarding management systems for hotel safety. This regulation stipulated all hotel owners to establish integrated safety systems to protect all consumers when they stayed in hotels. ${ }^{55}$

In financial services sector, Financial Services Authority (OJK) has enacted a regulation to provide stronger protection for consumers of financial services, which not only includes banking and insurance but also those related to investment activities. Every financial institution must provide transparency, fairness, confidentiality, reliability, and consumer data safety, as well as a simple, fast and affordable procedure for complaint and dispute resolution. Equally important, the directors of financial service providers are responsible for complying with this regulation, and are obliged to have a reporting and monitoring system to follow up on consumer complaints within a year after this regulation entered into force. ${ }^{56}$

With respect to dispute resolution, the existence of Consumer Dispute Settlement Body for resolving all kinds of consumer dispute in Indonesia has resulted in more formal procedures for resolving consumer disputes. It also provides more powerful legal sanctions. ${ }^{57}$ Moreover, this fact also reflects how judges play a dominant role that can be assumed as a hero figure of the third globalization. ${ }^{58}$ For example,

51 Governmental Regulation No. 69 of 1999 concerning Food Labeling and Advertising.

52 Mustaqim Adamrah, Govt to Launch New Body on Consumer Protection, The Jakarta Post, February, 17,2010,http:/ /www.thejakartapost.com/news/2010/02/17/govt-launch-new-body-consumerprotection.html

53 Kennedy, Op.Cit., 24.

54 Ministry of Transportation Decree No: PM 77 Tahun 2011 concerning Liability of Air Force Carrier.

55 Minister of Tourism and Creative Economy Decree No. PM.106 / PW.006 / mpek / 2011 of 2011 concerning Hotel Security Management System.

56 First OJK regulation increases customer protection, The Jakarta Post, July 31,2013, http://www. thejakartapost.com/news/2013/07/31/first-ojk-regulation-increases-customer-protection.html

57 Kagan, Op.Cit., 18.

58 Kennedy, Op.Cit., 65. 
in the Case law that involved Nissan Motor, Ludmilla Arief as a customer accused Nissan of lying about fuel efficiency of the Nissan March. She complained to Nissan after buying and using Nissan March that she was only getting 8 to 12 kilometers per liter of fuel from the car. However, Nissan's brochure said it could manage up to $21.8 \mathrm{~km} / \mathrm{L}^{59}$ As a result, Consumer Dispute Settlement Body decided that Nissan Motor had to buy back a car from its customer. ${ }^{60}$ Interestingly, after a long-winded process from Jakarta District Court and Jakarta Appellate Court, the Supreme Court of Indonesia finally affirmed the decision from this body. ${ }^{61}$

For Australia, competition and consumer protection used to be regulated under the Trade Practices Act 1974 and the Australian Securities and Investments Commission Act 2001 as well as the Corporations Act 2001.62 The Australian Competition and Consumer Commission is responsible for administration and enforcement of the Trade Practices Act. ${ }^{63}$ The Australian Securities and Investments Commission also has enforced consumer protection inrelation to financial services. ${ }^{64}$

The Australian Consumer Law has now replaced the Trade Practices Act and covers a suite of enforcement powers, penalties and remedies for breaches of consumer laws. ${ }^{65}$

The Australian Consumer Law also introduces a new set of enforcement powers, incuding the following: ${ }^{66}$

- civil pecuniary penalties;

- infringement notices allowing for minor infringements to be dealt with through the payment of small sums;

- disqualification orders, banning individuals from managing corporations or from engaging in specific forms of conduct;

- public warning notices, allowing for consumer agencies to warn the public

59 Rangga Prakoso, Indonesian Court Orders Nissan to Buy Back Gas-Guzzling Nissan March, The Jakarta Globe, April 17, 2012,http://www.thejakartaglobe.com/archive/indonesian-court-orders-nissanto-buy-back-gas-guzzling-nissan-march/

60 Consumer Dispute Settlement Body Decision No. 099/Pts.A/BPSK-DKI/II/2012.

61 Supreme Court of Indonesia Decision No. 659K/PDT.Sus/2013.

62 Arlen Duke, "Representations as to the Future Under the Proposed Australian Consumer Law,"Melbourne University Law Review 33, No. 2 (2009): 41.

63 Ibid.

64 Ibid.

65 http://consumerlaw.gov.au/consumer-policy-in-australia/resources/an-introduction-to-the-australian-consumer-law/

66 Ibid. 
about specific traders;

- substantiation notices, allowing consumer agencies to seek substantiation of claims made in trade or commerce; and

- consumer redress orders, allowing non-party consumers to obtain redress for breaches of the Law.

\subsection{The Incorporation of Local Wisdom}

It is undeniable that globalization has resulted in a new concept, idea, and perspective of law that can change social behavior of society. To adopt globalization of law and legal thought effectively, the process of legal transplantation and reception should incorporate local wisdom ${ }^{67}$ or an indigenous element. ${ }^{68}$ The transplant process will work better if it is compatible with pre-existing social norms or the living law of society. ${ }^{69}$ Then, it will encourage a better fit and generate sustained demand for further application, enforcement and development. ${ }^{70}$ The constitution of Indonesia expressly stated that the government recognizes and respects all of the traditional communities along with their traditional customary rights as long as they are exist, and are in accordance with the social development and the principles of the Unitary State of the Republic of Indonesia. ${ }^{71}$

In consumer protection, the incorporation of local wisdom can be identified from the provision that requires all entrepreneurs both foreign and local who produce and trade goods and services must follow halal production processes that are proven by a halal label. ${ }^{72}$ Basically, the halal term refers to things or actions permitted by Islamic law without imposing a punishment on the doer. It is usually used to describe food and drink that a Muslim is permitted to consume. ${ }^{73}$ For example, food or drink is halal if it does not contain pork or alcohol, and all forms of intoxicating and hazardous drinks. ${ }^{74}$ As a result, foreign entrepreneurs who wish to access the Indonesia's market will be pressured to adopt this provision. ${ }^{75}$ Furthermore, consumer protection law requires all entrepreneurs to include information or directions on the use of the goods in Indonesian language to conform with the prevailing provi-

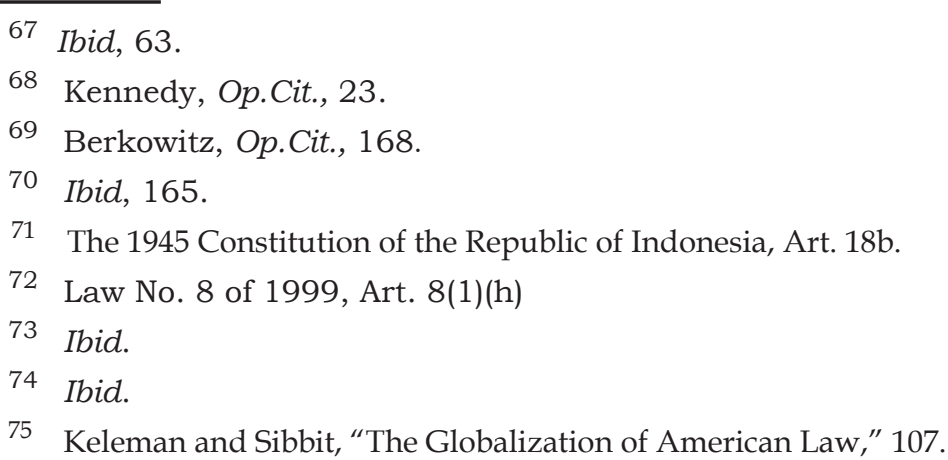


sions of the law. ${ }^{76}$

In Bali, entrepreneurs who want to develop a tourism destination should consider local wisdom based on Balinese belief, cultural tradition, and sustainable environment. ${ }^{77}$ Further more, they should give opportunities for local businesses who mainly produce handicrafts and agricultural products to exhibit their products in hotels and restaurants that are owned by those entrepreneurs. ${ }^{78}$ In addition, Bali's government requires the development of commercial buildings to adopt Bali's traditional architecture. ${ }^{79}$

For Australia, in 1999, the Aboriginal and Torres Strait Islander Commission (ATSIC) has established a national authenticity label, helping to protect Indigenous artists and their art work from forgery and piracy. ${ }^{80}$ One of the main purposes behind the scheme was to promote products made by indigenous people, and increase fair and equitable returns to indigenous producers. ${ }^{81}$ This system was created to overcome some of the problems associated with copyright law and consumer protection law where it can threaten the creativity of indigenous peoples although it still focused on regulating art and craft products for the tourist market. ${ }^{82}$

Australia also consistently promoted Australian local products through an 'Australian Made' campaign. ${ }^{83}$ This campaign revealed that there is a direct correlation between consumer purchasing behavior and employment, local economic development and prosperity. When Australian's buy Australian-made and grown products, they can be sure they are keeping their family members and friends employed. ${ }^{84}$

\section{CONCLUSION}

It is unmistakable that the globalization of legal services and convergence of legal systems significantly affects the law and regulations concerning consumer protection in Indonesia and Australia. The economic liberalization and political fragmentation are the salient factors to create more formal, transparent, and adversarial law and regulations that typically reflect to the Common Law system. The incorporation of local wisdom encourages receptiveness of globalization and convergence of

\footnotetext{
76 Law No. 8 of 1999, Art. 8(1)(j)

77 Provincial Regulation of Bali No. 2 of 2012 concerning Bali Cultural Tourism, Art.11.

78 Ibid.

79 Ibid., Art. 7.

80 Matthew Rimmer, "Australian Icons: Authenticity Marks and Identity Politics,"Indigenous Law Journal 3, No. 1 (2004): 139, 141.

81 Ibid.

82 Ibid.

83 http://www.australianmade.com.au/why-buy-australian-made/

84 Ibid.
} 
consumer protection in Indonesia and Australia.

\section{BIBLIOGRAPHY}

\section{Books}

Kagan, Robert A., Adversarial Legalism The American Way of Law, Boston: Harvard University Press, 2003.

Nonet, Philipe and Philip Selznik, eds. Law and Society in Transition: Toward Responsive Law, New York: Harper and Row, 1978.

Trubeck, David and Alvaro Santos, eds. The New Law \& Economic Development Movement: A Critical Appraisal, New York: Cambridge University Press, 2006.

Van den Bossche, Peter. The Law and Policy of The World Trade Organization, New York: Cambridge University Press, 2010.

Widiatedja, I Gusti Ngurah Parikesit. Liberalisasi Jasa dan Masa Depan Pariwisata Kita (Liberalization of Services and our Tourism Future), Denpasar: Udayana University Press, 2010.

\section{Journals}

Berkowitz, Daniel, Katharina Pistor, and Jean-Francois Richard. "The Transplant Effect." American Journal of Comparative Law, Vol.51 (2003).

Duke, Arlen. "Representations as to the Future Under the Proposed Australian Consumer Law.” Melbourne University Law Review 33, No. 2 (2009).

Haley, John Owen. "The Myth of the Reluctant Litigant." Journal of Japanese Studies 4 (2), No. 359 (1978).

Kelemen, Daniel R and Eric C. Sibbit. "The Globalization of American Law.” Journal of International Organization, Vol. 58 (2004).

Mattei,Ugo. "Three Patterns of Law: Taxonomy and the Change in the World's Legal Systems." American Journal of Comparative Law 45, No. 5 (1997).

Rimmer, Matthew. "Australian Icons: Authenticity Marks and Identity Politics." Indigenous Law Journal 3, No. 1 (2004). 


\section{Legal Documents}

Indonesia. The 1945 Constitution of the Republic of Indonesia . Indonesian Civil Code

. Law No. 7 of 1994 concerning the Ratification of Agreement on Establishing the World Trade Organization

. Law No.10 of 1998 concerning Banking Systems

. Law No. 8 of 1999 concerning Consumer Protection

. Law No. 36 of 1999 concerning Telecommunication

. Law No. 30 of 1999 concerning Arbitration Council

. Law No. 30 of 2000 concerning Trade Secret

. Law No. 32 of 2000 concerning Electronic Circuit Design

. Law No. 14 of 2001 concerning Patent

. Law No. 15 of 2001 concerning Trademark

. Law No. 19 of 2002 concerning Copyright

. Law No. 25 of 2007 concerning Investment

. Law No. 40 of 2007 concerning Limited Liability Company

. Law No. 11 of 2008 concerning Electronic Transaction

Law No. 10 of 2009 concerning Tourism

. Governmental Regulation No. 69 of 1999 concerning Food Labeling and Advertising

. Governmental Regulation No. 102 of 2000 concerning National Standardization

. Minister of Trade Decree No. 19/m-dag/per/5/2009 concerning Registration Manual and Card Guarantee/Warranty for Sale in Bahasa for Telematica and Electronic Products

. Minister of Trade Decree No. 20/m-dag/per/5/2009 concerning Rules and Procedures For Goods and/or Services Control

- Minister of trade decree No. 22/m-dag/per/5/2010 concerning Amendment of Minister of Trade Decree No. 62/m-dag/per/12/2009 concerning Responsibility of Label Inclusion in Goods 
. Minister of Tourism and Creative Economy Decree No. PM.106 / PW.006 / mpek / 2011 of 2011 concerning Hotel Security Management System . Ministry of Transportation Decree No: PM 77 Tahun 2011 concerning Liability of Air Force Carrier

. Provincial Regulation of Bali No. 2 of 2012 concerning Bali Cultural Tourism . The Supreme Court Regulation (PERMA) No. 1 of 2002 concerning Class Action

Australia. Trade Practices Act 1974 the Australian Securities and Investments Commission Act 2001 the Corporations Act 2001

\section{Case Law}

Civil Case Number 550/PDT.G/2000/PN.JKT.PST

Consumer Dispute Settlement Body Decision No. 099/Pts.A/BPSK-DKI/II/2012

Supreme Court of Indonesia Decision No. 659K/PDT.Sus/2013

\section{Internet}

Nababan, Eric. "Major Consumer Protection Law Enforcement and Consumer Issues in Indonesia." http://aseanconsumer.org/misc/downloads/usftc-s2Indonesia-Eric-Nababan.pdf

Rajagukguk, Erman. "The Prospect of Legal Institutions Reform in Indonesia." http: / /www.ermanhukum.com/Makalah\%20ER\%20pdf/The\%20Prospect\%20of\%20Legal\%20Institutions\%20Reform\%20in\%20Indonesia.pdf

Food and Agriculture Organization of the United Nations. "General Gudelines to Use the Term "halal." http:/ /www.fao.org/docrep/005/y2770e/y2770e08.htm

National Agency of Food and Drug Control. "Indonesia Food Recall System." http:/ / fscf-ptin.apec.org/docs / events / food-safety-recall-system-developmentand-strengthening/Appendix\%2019.pdf

Prakoso, Rangga. "Indonesian Court Orders Nissan to Buy Back Gas-Guzzling Nissan March, The Jakarta Globe." http://www.thejakartaglobe.com/archive/ indonesian-court-orders-nissan-to-buy-back-gas-guzzling-nissan-march/ 
Nurhayat, Wji. "Dalam 6 Bulan Ada 1700 Konsumen Mengadu ke BPKN (in Six Months, There Are 1700 Consumers Who Complaint to BPKN)." http://finance.detik.com/read/2013/12/11/133841/2438818/4/dalam-6-bulanada-1700-konsumen-ngadu-ke-bpkn?9911012

The Jakarta Post, "First OJK regulation increases customer protection." http:// www.thejakartapost.com/news/2013/07/31/first-ojk-regulation-increases-customer-protection.html , "1078 complaints to OJK in first half of 2014." http://www.thejakartapost. com/news/2014/06/16/1078-complaints-ojk-first-half-2014.html 